NASA Contractor Report 185243

AIAA-90-2000

\title{
Preliminary Design of a Long-Endurance Mars Aircraft
}

\author{
Anthony J. Colozza
}

Sverdrup Technology, Inc.

Lewis Research Center Group

Brook Park, Ohio

April 1990

Prepared for

Lewis Research Center

Under Contract NAS3-25266

\section{N/SA}





\title{
PRELIMINARY DESIGN OF A LONG-ENDURANCE MARS AIRCRAFT
}

\author{
Anthony J. Colozza \\ Sverdrup Technology, Inc. \\ Lew is Research Center Group \\ Brook Park, Ohio 44142
}

\section{Abstract}

The preliminary design requirements of a long-endurance aircraft capable of flight within the Martian environment were determined. Both radioi sotope/heat engine and PV solar array power production systems were considered. Various cases for each power system were analyzed in order to determine the necessary size, weight and power requirements of the aircraft. The analys is method used was an adaptation of the method developed by J.W. Youngblood and T.A. Talay of NASA Langley Research Center used to design a high-altitude Earth based aircraft. The analys is is set up to design an aircraft which, for the given conditions, has a minimum wingspan and maximum endurance parameter. The results showed that, for a first approximation, a long-endurance aircraft is feasible within the Martian envi ronment. The size and weight of the most efficient solar aircraft were comparable to the radioisotope powered one.

\section{Introduction}

This design study examines the feasibility of a long-endurance, remotely piloted aircraft capable of flight within the Martian environment. The flight duration time of this proposed aircraft would be on the order of 1 year. For an aircraft to fly continuously for this period of time, the power produc$t i$ on system must be based on an inexhaustible power source. There are two present day systems capable of meeting this requirement; they are: solar PV. arrays and a radioisotope heat source. Recent and projected advances in the power production, conversion and storage capabilities of these systems have made it possible to consider them for use on an aircraft.

Aside from the technical feasibility, this study was also prompted by the realization of the unique exploration and scientific data gathering potential obtainable with a long-endurance aircraft. Due to ability for controlled flight over large amounts of territory at low altitudes, an aircraft can perform tasks not possible by satellites, land rovers or balloons. There is a variety of mission scenarios which would be possible with a longendurance aircraft. These can range, for example, from magnetic and gravity field mapping to surveillance/reconnaissance missions.

Two types of aircraft were evaluated; one powered by solar cell arrays and the other by a radioisotope heat source. This evaluation was used to determine aircraft size, weight and power requirements for the chosen design points. The design points where characterized by being points of minimum wingspan and maximum endurance parameter. Maximum endurance refers to flying an aircraft at the airspeed which requires minimum power. There were various cases analyzed for each type of aircraft. The cases for the solar PV array powered aircraft varied in array efficiency and flight regime. The cases for the radioi sotope powered aircraft varied in heat source isotope.
Due to the Iow density of the Martian atmosphere (approximately equal to the atmospheric density at an altitude of $30.5 \mathrm{~km}$ on Earth) and the inherently low cruise velocity $(\sim 35 \mathrm{~m} / \mathrm{sec})$, the flight Reynolds number of the aircraft will be low $\left(\sim 10^{5}\right)$. This flight Reynolds number is similar to what birds and model planes fly at. Therefore the wings and propeller airfoils must be designed to accommodate low Reynolds number flow. This entails overcoming laminar boundary layer separation which can greatly increase the aircraft's parasite drag profile.

Another inherent problem which must be considered is the speed of sound within the Martian atmosphere. This parameter restricts the allowable rotation speed of the propeller to values for which the blade tip velocities remain subsonic. This is necessary to avoid the problems associated with shock waves forming on the blade tips. Due to the atmospheric composition (which is 95 percent $\mathrm{CO}_{2}$, 2.7 percent $\mathrm{N}_{2}$ and 1.6 percent $A r$ ) the speed of sound is nearly 30 percent less than the sea level speed of sound here on Earth.

The design constraints imposed by the Martian environment, such as those listed above, can greatly affect the shape or configuration of the aircraft. For an indepth design study, problems such as these would have to be considered in detail and the aircraft configuration al tered accordingly. However, since this is a feasibility study, design solutions to these problems have not been addressed.

\section{Background}

The concept of designing an aircraft capable of sustained flight in the Martian atmosphere began wi th the development of high-altitude Earth based aircraft. The atmospheric density encountered at approximately $30.5 \mathrm{~km}$ on Earth is similar to that encountered near the surface of Mars. Therefore, an aircraft designed to fly at this altitude on Earth would be similar, aerodynamically, to the design needed to fly on Mars. In order to be applicable to this study, these Earth based aircraft would also need to be nonairbreathing and capable of $f$ light for extended periods of time.

The first aircraft design which met some of these requirements was the mini-sniffer developed by NASA Drydren. This aircraft was capable of sustained flight at up to $30.5 \mathrm{~km}$. It was designed as a low cost alternative for atmospheric research. 0 ther Earth based missions expressed a need for a high-altitude aircraft which could fly for up to a year nonstop. This concept spawned a variety of studies performed by NASA Langley Research Center and Lockheed to develop such an aircraft. The aircraft was designated high altitude powered platform (HAPP) 1-4 It was solar powered and had a regenerative fuel cell energy storage system. The HAPP study was led by J.W. Youngblood of NASA Langley.

Besides the mini-sniffer and HAPP, there were other aircraft which directly or indirectly had 
characteristics that were applicable to a Mars aircraft. Some of these are as follows: Gossamer Penguin and Solar Challenger sponsored by the Dupont Company, 5 project Sunrise developed by Astro Flight Inc. 6 and the Low Altitude/Airspeed Unmanned Research Aircraft (LAURA) developed by the Naval Research Lab. 7

There is not much information available on the explicit design of a Mars based aircraft. There was, however, one study published by Development Sciences Incorporated in which they presented a design of a remotely piloted Mars aircraft for the Jet Propulsion Lab.8 The main reason this study could not be directly used was that the aircraft was designed for short duration flight only. Therefore there were no extended power production or storage methods incorporated into the design. However, some of the concepts which were presented, such as deployment, stowage and airfoil design could be applied to this study.

\section{Me thod of Analys is}

The flight requirements of the HAPp are very similar to those that would be required for a longendurance Mars aircraft. Therefore, the method used to design the HAPP was used to develop the design points for both the solar PV and radioisotope powered aircraft presented in this study. This was accomplished by altering the HAPP design method to reflect the conditions present on Mars. The values used to characterize the Martian environment are listed in the Environment section of this paper.

The analysis of both types of aircraft was kept as similar as possible so that the comparison between them would be accurate. The only difference between the methods (for obtaining design points) is the deletion of the energy balance diagram, and the incorporation of structural sizing equations into the radioisotope aircraft design. The structural sizing equations are necessary because the output or size of the radioisotope power source is not directly coupled to the wing area and hence structural mass of the aircraft. So for a given aircraft configuration; the size of the radioisotope power production system could be increased to the point where enough power is produced to enable the configuration to fly aerodynamically but not structurally. In order to correct this situation, the structural sizing equations are used to check the airframe mass allotted by the analysis with that required for flight. This insured that the data points selected are physically realistic with respect to structural mass.

A detailed description of the analysis, for both types of aircraft, is contained within the Appendix. The data points produced represent minimum area/maximum endurance parameter solutions. A graph showing the design method output is given in Fig. 1. This graph consists of points produced for a solar powered aircraft with 25 percent efficient solar PV cells and a maximum latitude range of $55^{\circ} \mathrm{N}$. to $55^{\circ} \mathrm{S}$. Any points at or above the data point line on Fig. 1 have lift coefficients which produce endurance parameters that exceed those required by the energy balance diagram for nonstop flight. Therefore, all sizing points above the data point line represent aircraft which are capable of flying with the conditions specified for this test case. However, aircraft sizes which are above the data point line are not minimum area points.

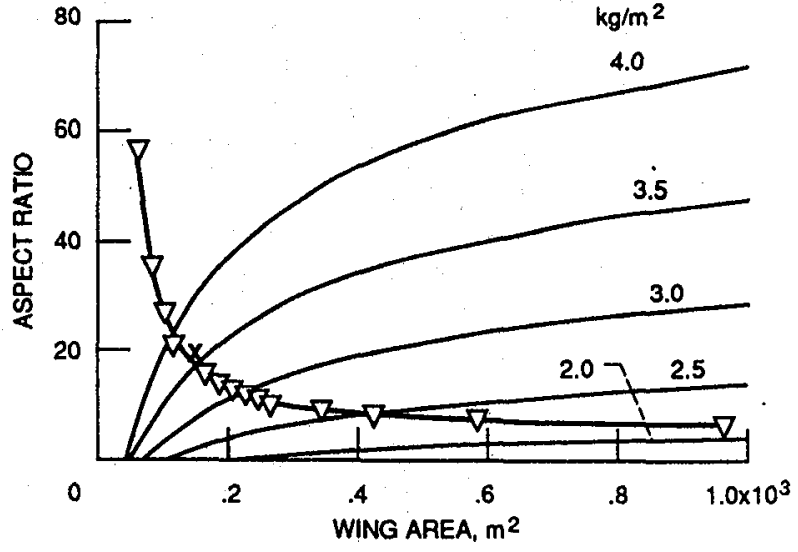

Figure 1. - Maximum endurance parameter minimum area curve.

In order to produce the design point, represented by the $X$ in Fig. 1 , the criteria for minimum wingspan was used. A plot of wingspan for the minimum area/maximum endurance parameter points is given in Fig. 2. The minimum wingspan point was selected of $\mathrm{f}$ this curve and used as the design

point on Fig. 1. The actual design point chosen is slightly above the minimum area/maximum endurance parameter curve. This was done in order to build some margin of error into the aircraft specifications which are calculated from the design point. All design points for both types of aircraft were obtained in a similar manner.

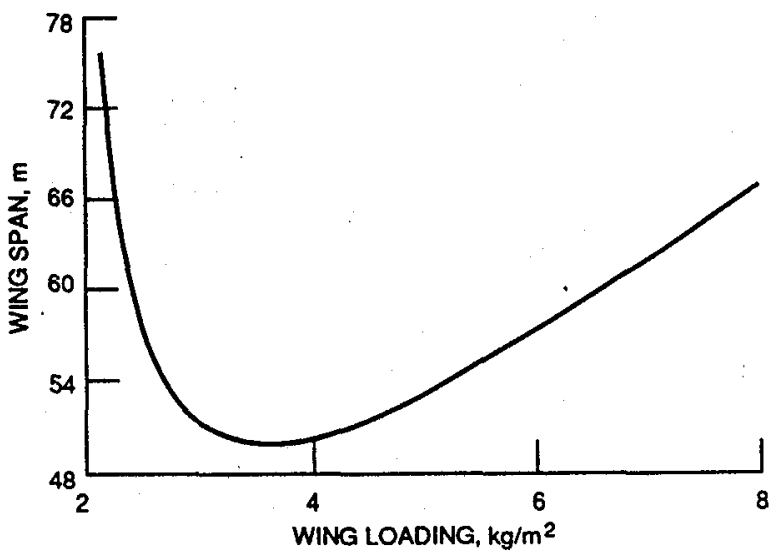

Figure 2. - Wing span for minimum area maximum endurance parameter points.

\section{Envi ronment}

The Martian environment is very different from what we are accustomed to on Earth. Mars is a harsh cold place with a very thin atmosphere. With the proper design, which takes into account the various environmental factors, it is, however, possible to generate sufficient lift to enable an aircraft to sustain controlled flight within this atmosphere.

For this study, there was no specific flight path chosen. Therefore, average quantities were used for some of the environmental conditions. These quantities are as follows:

Rotation rate: $24 \mathrm{hr} 37 \mathrm{~min} 23 \mathrm{sec}$ Inclination to orbital plane: $25.2^{\circ}$ Average atmospheric density: $0.016 \mathrm{~kg} / \mathrm{m}^{3}$ Mean temperature at surface: $218 \mathrm{~K}$ Mean distance from the Sun: $227 \mathrm{M} \mathrm{km}(1.52 \mathrm{au})$ 
Surface gravity: 38 percent of Earth

$\left(\mathrm{g}=3.75 \mathrm{~m} / \mathrm{sec}^{2}\right)$

Albedo: 0.37

Solar intensity at Mars orbit: $580.5 \mathrm{~W} / \mathrm{m}^{2}$

\section{Mission/Design Constraints}

This design method is set up to obtain optimum values for various quantities wi thout specifying any major parameters of the aircraft, such as size, power or flight speed. Therefore the aircraft design is not constrained and the optimum configura$t$ ion can be determined. There are, however, some minor specifications which must be given in order for the results to be generated. These specifications, which were used for both types of aircraft, are given below. They can be altered to accommodate different mission requirements which will result in variations in the design specifications obtained by this analysis.

Rate of climb: $0.1 \mathrm{~m} / \mathrm{sec}$

Payload: $100 \mathrm{~kg}$

Payload power: $100 \mathrm{~W}$

Tail surface area: 33 percent of wing surface area

Structural load factor: 4.0

Twin tail boom configuration

Under wing mounted fuselage with single pusher propeller

The structural load factor is used to increase the allotted structural design strength to take into account the loads on the structural members due to accelerations. Acceleration loads can occur from ei ther maneuvering or wind gusts. For steady level flight the required structural load factor would be 1 .

\section{Solar Powered Aircraft Results}

There were two cases tested for the solar powered aircraft. The first case used silicon solar cells and the second used gallium arsenide solar cells. Calculations were performed for both cases at lat. 0 and $5^{\circ} \mathrm{N}$. during winter solstice in the northern hemisphere. Winter solstice was chosen because it is the time of lowest solar intensity in the northern hemisphere. Therefore the analysis was a worst case scenario for each latitude tested.

Just considering solar availability, the aircraft designed to $f$ ly at lat. $5^{\circ} \mathrm{N}$. would be able to travel in the region from lat. $55^{\circ} \mathrm{S}$. to lat. $55^{\circ} \mathrm{N}$. if its flight path followed the seasons for a period of 1 Martian year. Similarly the aircraft designed for lat. $0^{\circ} \mathrm{N}$. would be able to fly from lat. $50^{\circ} \mathrm{S}$. to lat. $50^{\circ} \mathrm{N}$. The flight regime for winter solstice is shown in Fig. 3. Cases can be tried for higher latitudes in order to expand the flight regime; however, as the latitude increases the aircraft size becomes prohibitively large.

Therefore, it can be concluded that it would be difficult, if not impossible, to produce a solar powered aircraft which can fly to the polar regions.

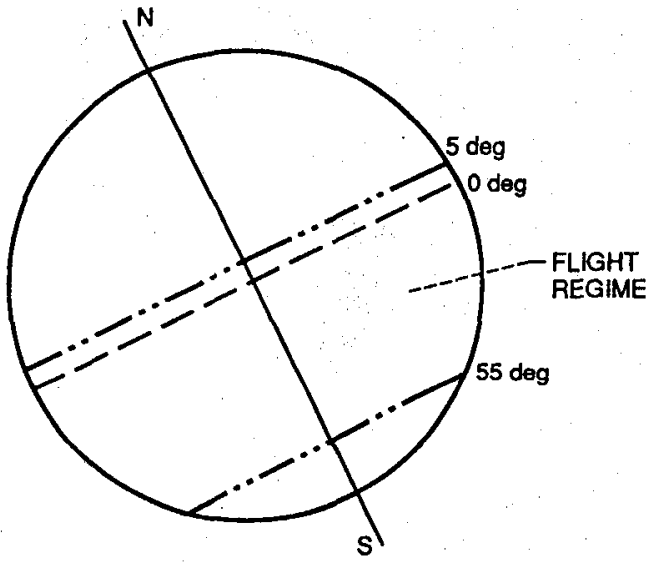

Figure 3. - Flight regime for solar aircraft during winter solstice in the northern hemisphere.

The propulsion and power specifications used in the analysis for both types of arrays are contained in Table 1. These systems consist of solar PV array panels, a regenerative fuel cell and electric motor. A diagram of the system configuration is shown in Fig. 4. The array panels are located on the wings, tail and fuselage. The regenerative fuel cell, used for energy storage, uses gaseous hydrogen and oxygen as the reactants. For propulsion, an electric motor is used with a gear box (to adjust propeller revolutions per minute) and a pusher propeller.

The fuel cells and electric motor will need to be cooled. One possible way of accomplishing this is by using a combination of atmospheric cooling and heat pipes incorporated as part of the aircraft struc ture.

The results obtained from the analysis of the solar powered aircraft are contained in Tables 2 to 6 . Table 2 contains all the geometric factors for the various aircraft types. As would be expected, an increase in efficiency of the solar cells brings a substantial decrease in wing area. Therefore as

TABLE 1. - PROPULSION AND POWER DATA FOR AIRCRAFT WITH

SILICON AND GaAs CELLS

\begin{tabular}{|l|r|r|}
\hline \multirow{2}{*}{} & \multicolumn{2}{|c|}{ Solar cell type } \\
\cline { 2 - 3 } & Silicon & \multicolumn{1}{|c|}{$\begin{array}{c}\text { GaAs, } \\
\text { percent }\end{array}$} \\
\hline Solar cell efficiency, percent & & \\
Solar ce:l specif ic weight, kg/m & 14.2 & 25.0 \\
Fuel cell efficiency, percent & 0.734 & 0.5 \\
Fuel cell specific energy, Wh/kg & 60.0 & 60.0 \\
Propulsion system efficiency, percent & 440.0 & 440.0 \\
Propulsion system specific energy, W/kg & 75.0 & 75.0 \\
\end{tabular}




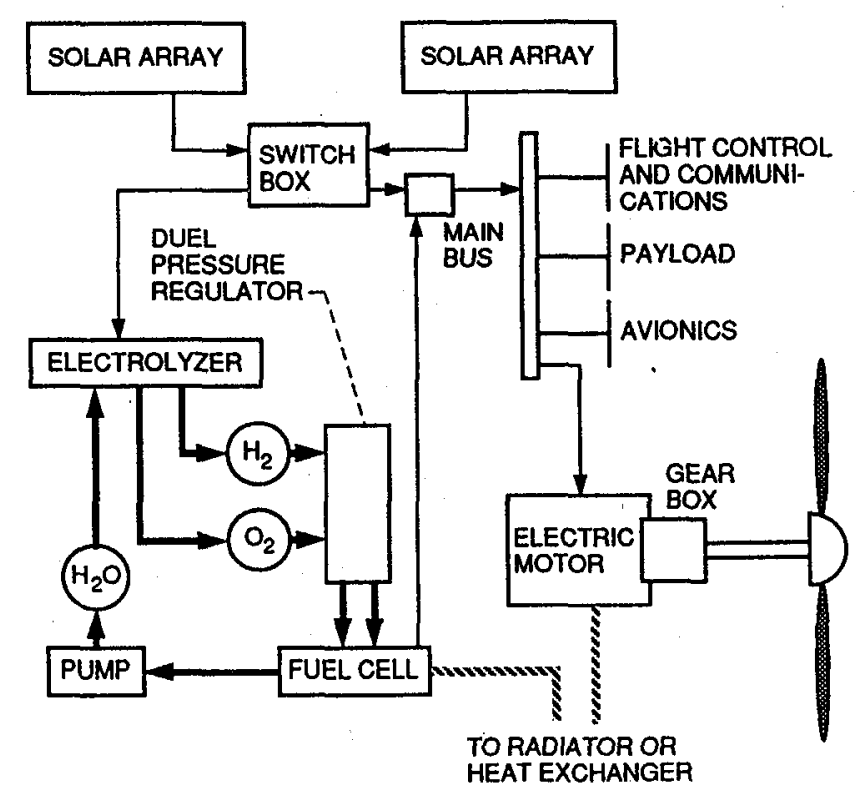

Figure 4. - Solar powered aircraft power and propulsion system diagram. the solar array efficiency goes up, the solar powered aircraft becomes more feasible. The size and aspect ratio needed by the aircraft using 14.2 percent efficient cells are at the edge of what is possible to construct with today's technology. It should be noted that as the flight regime is restricted, a considerable decrease in wing area and aspect ratio is realized. However, even at the equator (lat. $0^{\circ}$ ) during winter solstice, the wingspan needed is still over $100 \mathrm{~m}$. There are many problems with wingspans of this length such as deployment, stowage and stabilization. By using higher efficiency cells the results are much more realistic.

Tables 3 and 4 contain the weight requirements for the various components of the aircraft. The required airframe weight is determined by the structural sizing calculations contained in the Appendix. The specific breakdown for these calculations is in Table 4. After reviewing the airframe weights of various ultralight gliders and some of the aircraft listed in the references, it can be concluded that the various weights given by these calculations are conservative and that actual component weights could be substantially less then what is predicted. These calculations do however provide a guideline on which

TABLE 2 . - SOLAR POWERED AIRCRAFT GEOMETRY SPECIFICATION FOR VARIOUS SOLAR CELL EFFICIENCIES AND MAXIMUM NORTH LATITUDES

\begin{tabular}{|l|r|r|r|r|}
\hline & \multicolumn{3}{|c|}{ Solar cell efficiency, percent } \\
\cline { 2 - 5 } & \multicolumn{3}{|c|}{14.2} & \multicolumn{2}{|c|}{25} \\
\cline { 2 - 5 } & \multicolumn{4}{|c|}{ Latitude, deg } \\
\cline { 2 - 5 } & $5 \mathrm{~N}$. & 0 & $5 \mathrm{~N}$. & 0 \\
\hline Wing loading, $\mathrm{kg} / \mathrm{m}^{2}$ & 3.58 & 3.54 & 3.41 & 3.69 \\
Wing area, m & 405.00 & 336.00 & 166.33 & 118.75 \\
Wing span, m & 128.00 & 108.00 & 51.60 & 47.50 \\
Aspect ratio & 40.50 & 35.00 & 16.00 & 19.00 \\
\hline
\end{tabular}

TABLE 3. - SOLAR POWERED AIRCRAFT WEIGHT BREAKDOWN FOR VARIOUS SOLAR CELL EFFICIENCIES AND MAXIMUM NORTH LATITUDES

\begin{tabular}{|l|r|r|r|r|}
\hline \multirow{2}{*}{} & \multicolumn{3}{|c|}{ Solar cell efficiency, percent } \\
\cline { 2 - 5 } & \multicolumn{3}{|c|}{14.2} & \multicolumn{2}{|c|}{25} \\
\cline { 2 - 5 } & \multicolumn{4}{|c|}{ Latitude, deg } \\
\cline { 2 - 5 } & $5 \mathrm{~N}$. & 0 & $5 \mathrm{~N}$. & \multicolumn{1}{c|}{0} \\
\hline Airframe, allotted kg & 876.19 & 751.82 & 238.37 & 170.85 \\
Airframe, required kg & 475.66 & 384.53 & 209.95 & 161.64 \\
Propulsion, kg & 29.98 & 26.84 & 21.93 & 16.87 \\
Solar cells, kg & 268.17 & 159.60 & 79.00 & 56.41 \\
Fuel cell, kg & 175.55 & 151.18 & 126.86 & 94.07 \\
Payload, kg & 100.00 & 100.00 & 100.00 & 100.00 \\
Total, kg & 1149.90 & 1189.44 & 567.16 & 438.20 \\
\hline
\end{tabular}


TABLE 4. - SOLAR POWERED AIRCRAFT AIRFRAME WEIGHT BREAKDOWN FOR VARIOUS SOLAR CELL EFFICIENCIES AND MAXIMUM NORTH LATITUDES

\begin{tabular}{|l|r|r|r|r|}
\hline \multirow{2}{*}{} & \multicolumn{3}{|c|}{ Solar cell efficiency, percent } \\
\cline { 2 - 5 } & \multicolumn{3}{|c|}{14.2} & \multicolumn{2}{|c|}{25} \\
\cline { 2 - 5 } & \multicolumn{4}{|c|}{ Latitude, deg } \\
\cline { 2 - 5 } & $5 \mathrm{~N}$ & 0 & $5 \mathrm{~N}$ & \multicolumn{1}{|c|}{0} \\
\hline Mass spar, kg & 141.38 & 98.33 & 20.43 & 18.79 \\
Mass leading edge, kg & 59.92 & 53.48 & 39.15 & 25.65 \\
Mass trailing edge, kg & 12.77 & 10.77 & 5.15 & 4.74 \\
Mass covering, kg ribs, kg & 83.18 & 69.01 & 39.16 & 24.42 \\
Mass control devices, kg & 37.81 & 33.80 & 22.17 & 18.11 \\
Mass fuselage, kg & 19.13 & 17.07 & 12.50 & 8.19 \\
Mass tail, kg & 74.74 & 56.78 & 37.08 & 18.84 \\
Mass propeller, kg & 27.29 & 25.96 & 20.34 & 23.17 \\
\end{tabular}

TABLE 5. - SOLAR POWERED AIRCRAFT AERODYNAYIC DATA FOR VARIOUS SOLAR CELL EFFICIENCIES AND MAXIMUM NORTH LATITUDES

\begin{tabular}{|l|r|r|r|r|}
\hline \multirow{2}{*}{} & \multicolumn{3}{|c|}{ Solar cell efficiency, percent } \\
\cline { 2 - 5 } & \multicolumn{2}{|c|}{14.2} & \multicolumn{2}{|c|}{25} \\
\cline { 2 - 5 } & \multicolumn{4}{|c|}{ Latitude, deg } \\
\cline { 2 - 5 } & $5 \mathrm{~N}$. & 0 & $5 \mathrm{~N}$. & \multicolumn{1}{c|}{0} \\
\hline Endurance parameter & 58.26 & 53.19 & 29.59 & 30.91 \\
$\mathrm{C}_{1}$ & 1.71 & 1.88 & 1.38 & 2.47 \\
$\mathrm{C}_{\mathrm{d}}$ & 0.038 & 0.048 & 0.055 & 0.126 \\
Velocity, m/sec & 44.54 & 38.79 & 25.09 & 19.67 \\
& 31.33 & 29.71 & 34.03 & 26.46 \\
\hline
\end{tabular}

TABLE 6. - SOLAR POWERED AIRCRAFT POWERED SPECIFICATIONS FOR VARIOUS SOLAR CELL EFEICIENCIES AND MAXIMUM NORTH LATITUDES

\begin{tabular}{|l|r|r|r|r|}
\hline \multirow{2}{*}{} & \multicolumn{3}{|c|}{ Solar cell efficiency, percent } \\
\cline { 2 - 5 } & \multicolumn{3}{|c|}{14.2} & \multicolumn{2}{|c|}{25} \\
\cline { 2 - 5 } & \multicolumn{4}{|c|}{ Lat itude, deg } \\
\cline { 2 - 5 } & $5 \mathrm{~N}$ & 0 & $5 \mathrm{~N}$ & 0 \\
\hline Power required, W & 4951 & 4454 & 3729 & 2847 \\
Power reserve, W & 544 & 446 & 213 & 164 \\
Power payload, W & 100 & 100 & 100 & 100 \\
Total power requi red, W & 5595 & 5000 & 4042 & 3111 \\
\hline
\end{tabular}


to base the aircraft structural weight. If the allotted airframe weight is slightly greater or less than the required airframe weight obtained by the structural sizing equations, it is realistic to assume that this airframe can be built with today's materials and meet the necessary structural requirements of the aircraft. Any savings in airframe weight over that allotted by the design analys is cąn be considered usable as extra payload.

Table 5 contains the required aerodynamic data for the aircraft. The cruising velocity of the aircraft for all cases is fairly slow $(\sim 30 \mathrm{~m} / \mathrm{sec})$. This low cruising velocity also contributes to the low flight Reynolds number discussed previously.

The last data table (Table 6) contains the power requirements of the aircraft. As the solar cell efficiency increases, the size of the aircraft is reduced and, therefore, the power required for cruising flight is reduced. The reserve power is used for maneuvering and stabilization of the aircraft. If an increase in rate of climb is desired, the power allotted for reserve would have to be increased. To effectively increase the rate of climb without increasing the power collection capability, the aircraft could be designed so that when climbing, all power, except that for vital systems, is sent to the engine, and during cruising, the reserve power could be used for the payload or for recharging the fuel cells. Another method of increasing the rate of climb is to carry excess fuel cell reactants. During long periods of daytime cruising the reserve power could be used to regenerate the fuel cells to a capacity greater than that which is needed for nighttime flight. Therefore, if rapid maneuvering is required, the reserve powe 5 along with the power produced by the excess fuel cell reactants can be utilized. If an efficient power utilization system is developed, the maneuverability of the aircraft can be increased without requiring added solar collection capability.

\section{Radioisotope Powered Aircraft Results}

As an alternative to solar power, two radioisotope power sources were analyzed. The heat-source materials considered were plutonium 238 and curium 244. Pu 238 is the standard material for the general purpose heat source (GPHS) used in all radioisotope generators. The $\mathrm{Pu} 238$ heat source has a specific energy of $73.53 \mathrm{~W} / \mathrm{kg}$ and a half-life of 87 years. Therefore, there is little effect on fuel depletion over a mission time of 2 to 3 years.

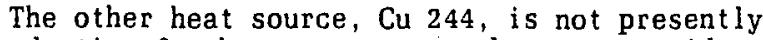
in production for heat source use, but was considered as a possible fuel because of its very high specific energy $(534.76 \mathrm{~W} / \mathrm{kg})$. Its half-life of 18 years is considerably shorter than that of $\mathrm{Pu}$. However, because of its high specific energy and a mission time of around 3 years, this is not a problem. If this isotope were to be used, it would be enclosed in capsules similar to that of the GPHS with modifications made to accommodate the higher specific energy and heat. Before a heat source using this isotope could be put into use, a lengthy and expensive development, production and certification process would have to be completed. Even though $\mathrm{Cm} 244$ enables an eight-fold power increase over $\mathrm{Pu} 238$, the cost and time necessary to get the isotope certified may be prohibitive.
A Brayton cycle heat engine was chosen to convert the heat energy generated by the radioisotope heat source to mechanical and electrical energy. This type of heat engine was chosen for two main reasons. First, it has proven operation at the power levels required by the aircraft; and second, the working fluid is not sealed within the engine, thus allowing direct utilization of the large wing areas for heat rejection. The efficiency of the heat engine at the power levels needed by the aircraft is 35 percent and its specific power is

$55 \mathrm{~W} / \mathrm{kg}$. The propeller used in conjunction with the heat engine to produce thrust was given an efficiency of 85 percent, which is an average value for present day aircraft. A diagram of the radioisotope propulsion and power system is given in Fig. 5 .

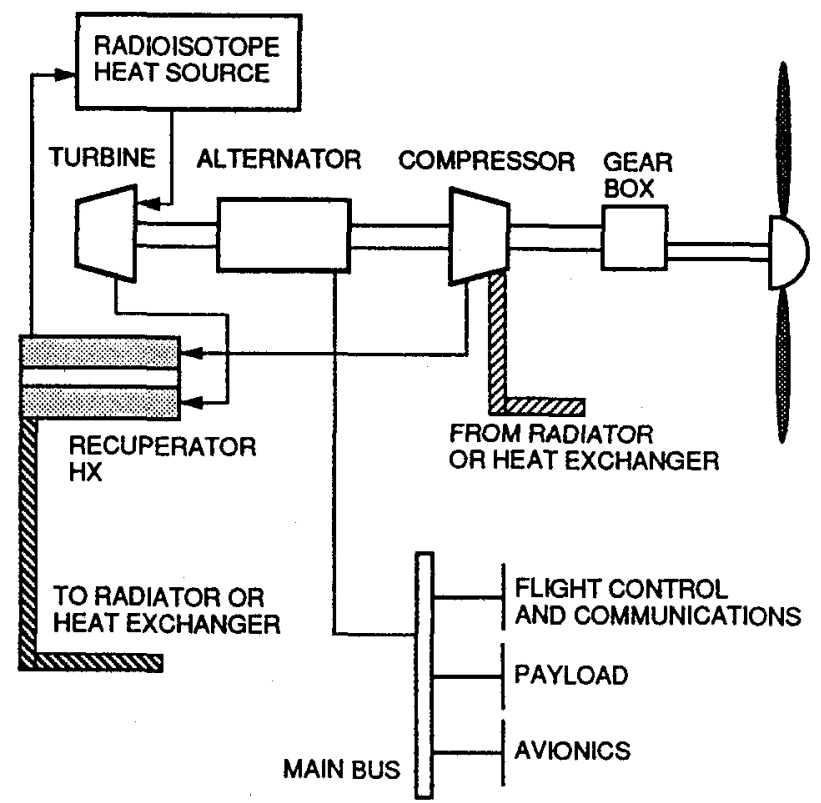

Figure 5. - Radioisotope powered aírcraft power and propuision system diagram.

The results for the radioisotope powered aircraft analysis are given in Tables 7 to 11 . These tables are set up similarly to those for the solar powered aircraft results. The wing area needed with the $\mathrm{Cm}$ heat source was slightly less then that with $\mathrm{Pu}$. The results suggest that the size of the Pu 238 powered aircraft is similar to that of the GaAs solar powered aircraft.

The average cruising velocity for the various radioisotope powered aircraft is slightly higher than $40 \mathrm{~m} / \mathrm{sec}$. This is approximately $10 \mathrm{~m} / \mathrm{sec}$ greater than the solar powered aircraft. The average thermal watts needed to be generated by the isotope fuel is just over $10000 \mathrm{~W}$ for $\mathrm{Pu} 238$ and just over $7000 \mathrm{~W}$ for $\mathrm{Cm} 244$.

\section{Conclusion}

This study has shown that, for a first approximation, a long endurance aircraft is possible within the Martian environment using solar PV or radioisotope power systems. The necessary sizes of the aircraft are fairly large, but not too far beyond the realm of what is currently being built today for ultralight gliders. 
TABLE 7. - RADIOISOTOPE POWERED AIRCRAFT GEOMETRY WITH PU 238 AND

Cm 244 HEAT SOURCES

\begin{tabular}{|l|r|r|}
\hline \multirow{2}{*}{} & \multicolumn{2}{|c|}{ Power source } \\
\cline { 2 - 3 } & Pu 238 & \multicolumn{1}{|c|}{ Cm 244 } \\
\hline Wing loading, kg/m & 3.61 & 2.99 \\
Wing area, m & 145.00 & 103.00 \\
Wing span, m & 48.20 & 37.97 \\
Aspect ratio & 16.00 & 14.00 \\
\hline
\end{tabular}

TABLE 8. - RADIOISOTOPE POWERED AIRCRAFT WEIGHT BREAKDOWN WITH Pu 238 AND Cm 244 HEAT SOURCES

\begin{tabular}{|l|r|r|}
\hline & \multicolumn{2}{|c|}{ Power source } \\
\cline { 2 - 3 } & \multicolumn{1}{|c|}{ Pu 238 } & \multicolumn{1}{c|}{ Cm 244 } \\
\hline Airf rame, alloted kg & 215.25 & 147.39 \\
Airframe, required kg & 213.70 & 161.87 \\
Propulsion, kg & 65.90 & 46.82 \\
Isotope, kg & 140.80 & 13.76 \\
Payload, kg & 100.00 & 100.00 \\
Total, kg & 521.95 & 307.97 \\
\hline
\end{tabular}

TABLE 9. - RADIOISOTOPE POWERED AIRCRAFT AIRFRAME WEIGHT BREAKDOWN

WITH Pu 238 AND Cm 244 HEAT SOURCES

\begin{tabular}{|c|c|c|c|c|c|}
\hline & \multicolumn{5}{|c|}{ Power source } \\
\hline & \multicolumn{3}{|c|}{$\mathrm{Pu} 238$} & \multicolumn{2}{|c|}{$\mathrm{Cm} 244$} \\
\hline & \multicolumn{5}{|c|}{ Total power, Ptot, $W$} \\
\hline & 20 & 25 & 30 & 20 & 25 \\
\hline Mass spar, kg & 16.48 & 18.56 & 21.72 & 8.89 & 9.57 \\
\hline Mass leading edge, kg & 38.40 & 34.13 & 25.92 & 29.77 & 25.92 \\
\hline Mass trailing edge, $\mathrm{kg}$ & 4.85 & 4.81 & 4.62 & 3.84 & 3.79 \\
\hline Mass covering, $\mathrm{kg}$ & 32.61 & 29.93 & 24.78 & 23.54 & 21.27 \\
\hline Mass ribs, $\mathrm{kg}$ & 21.54 & 20.46 & 18.78 & 17.71 & 16.66 \\
\hline Mass control devices, kg & 12.26 & 10.90 & 8.28 & 9.50 & 8.28 \\
\hline Mass fuselage, kg & 29.93 & 54.00 & 65.49 & 31.05 & 40.53 \\
\hline Mass tail, $\mathrm{kg}$ & 18.52 & 21.41 & 25.82 & 15.77 & 17.68 \\
\hline Mass propeller, kg & 18.18 & 19.50 & 21.23 & 16.88 & 17.77 \\
\hline
\end{tabular}

TABLE 10. - RADIOISOTOPE POWERED AIRCRAFT AERODYNAMIC DATA WITH Pu 238 AND Cm 244 HEAT SOURCES

\begin{tabular}{|l|r|r|}
\hline \multirow{2}{*}{} & \multicolumn{2}{|c|}{ Power source } \\
\cline { 2 - 3 } & Pu 238 & Cm 244 \\
\hline Endurance parameter & 27.58 & 20.67 \\
$\mathrm{C}_{\mathrm{l}}$ & 0.89 & 0.80 \\
$\mathrm{C}_{\mathrm{d}}$ & 0.031 & 0.035 \\
$\mathrm{~L} / \mathrm{D}$ & 29.23 & 27.00 \\
Velocity, m/sec & 43.54 & 41.86 \\
\hline
\end{tabular}

TABLE 11. - RADIOISOTOPE POWERED AIRCRAFT POWER SPECIFICATIONS

WITH Pu 238 AND Cm 244 HEAT SOURCES

\begin{tabular}{|l|r|r|}
\hline \multirow{2}{*}{} & \multicolumn{2}{|c|}{ Power source } \\
\cline { 2 - 3 } & Pu 238 & Cm 244 \\
\hline Power shaft, W & 3625 & 2575 \\
Power reserve, W & 196 & 116 \\
Power payload, W & 100 & 100 \\
Power isotope, W & 10357 & 7358 \\
\hline
\end{tabular}


There is no clear-cut winner as far as which type of power system should be used. Both types have advantages and disadvantages. The deciding factor will depend greatly on the proposed mission scenario.

Of the two types of aircraft, the radioisotope one is inherently more versatile. It is capable of flying to all regions of the planet regardless of time of year. There is no loss in power due to decreases in solar flux, which is a concern with the solar powered aircraft. And for near-term production, its size and weight are less than that of the solar aircraft due to the low efficiencies of the present day solar arrays. However, as the efficiency of solar arrays increase, the necessary size and weight of a solar powered aircraft becomes comparable with that of a radioisotope powered one. If the aircraft were to be used in conjunction with a manned base, solar power eliminates any radiation hazard. However, it should be noted that, even with 30 percent or more efficient solar arrays, it is very unlikely that a solar powered, long endurance aircraft can be built which is capable of traveling to the polar regions on Mars.

The cost of a system is always a major consideration. In this area, solar power has a distinct advantage. Ignoring the developmental costs, the high cost of producing the quantity of isotope needed for the radioisotope powered system would be far greater than the cost of a comparably powered solar array.

In either case, there are still many areas which must be addressed before definite conclusions on the abilities of either type of aircraft are drawn. If further work on this subject is warranted, the following areas should be analyzed in greater detail.

1. A definite flight plan should be designated to enabling a more accurate modeling of the environmental conditions such as atmospheric density, temperature and wind.

2. An indepth analysis of the solar radiation collectible by the arrays should be performed, taking into account the variations in atmospheric density, dust and diffuse and reflected radiation. Also, the possibility of movable or variable geometry wings to increase collected solar radiation should be addressed.

3. The radiator system for both types of aircraft needs to be specified in greater detail in order to obtain accurate figures of merit for the system. Because of the large amount of available wing area, the incorporation of a specific radiator into the design should not be that difficult. In this design, an approximation of the radiator mass was incorporated into the propulsion and power system mass.

4. A deployment scheme for the aircraft should be devised. This scheme could be anything from assembly of the plane at a manned base or automatic deployment upon atmospheric entry. The deployment and, if desirable, landing scheme will evidently depend greatly on the type of mission.

The basic characteristics which have been established by this study can be used as a basis for determining which type of aircraft and technology

developments would be necessary for a given mission. The ability of a long-endurance aircraft, either solar or radioisotope powered, capable of flying in the Martian atmosphere seems possible and could be considered as an option for any Mars exploration mission. An artists conception of this aircraft is shown in Fig. 6. The use of such a craft for either manned or unmanned missions could greatly enhance the ability to explore our neighbor, the red planet.

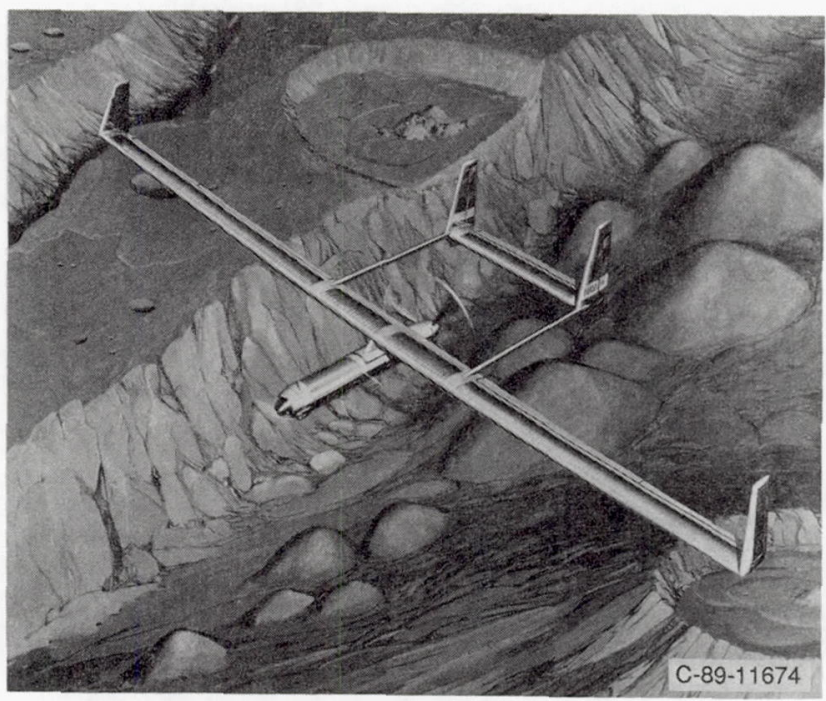

Figure 6. - Artists conception of solar powered Mars aircraft.

Appendix

\section{Symbols}

AR

b

$\mathrm{C}_{\mathrm{d}}$

$\mathrm{C}_{\mathrm{d}_{\text {boom }}}$

$\mathrm{C}_{\mathrm{d}_{\text {induced }}}$

$\mathrm{C}_{\mathrm{d}}$ parasite

$\mathrm{C}_{\mathrm{d} \text { pod }}$

$\mathrm{C}_{\mathrm{tai}}$

$\mathrm{C}_{\text {total }}$

$\mathrm{C}_{\mathrm{d}_{\text {wing }}}$

$C_{\text {I }}$

$\mathrm{C}_{\text {wind }}$

F

$\mathrm{M}_{\mathrm{af}}$

$M_{\text {Con }}$

$\mathrm{M}_{\mathrm{COV}}$

$\mathrm{M}_{\mathrm{fC}}$

M fus aspect ratio

wingspan, m

drag coefficient

tail boom drag coefficient

induced drag coefficient

parasite drag coefficient

fuselage pod drag coefficient

tail drag coefficient

total drag coefficient

wing drag coefficient

lift coefficient

wind 1 ift coefficient

fuel cell specific energy, Wh/ $\mathrm{kg}$

air frame mass, $\mathrm{kg}$

control mass, $\mathrm{kg}$

cover mass, $\mathrm{kg}$

fuel cell mass, kg

fuselage mass, $\mathrm{kg}$ 


\begin{tabular}{|c|c|}
\hline Mhs & heat source mass, $\mathrm{kg}$ \\
\hline $\mathrm{M}_{\mathrm{le}}$ & leading edge mass, $\mathrm{kg}$ \\
\hline $\mathrm{M}_{\mathrm{p}}$ & propeller mass, kg \\
\hline$M_{p l}$ & payload mass, kg \\
\hline$M_{\text {prop }}$ & propulsion system mass, $\mathrm{kg}$ \\
\hline$M_{r}$ & ribs mass, $\mathrm{kg}$ \\
\hline $\mathbf{M}_{\mathbf{S}}$ & spar mass, $\mathrm{kg}$ \\
\hline$M_{\text {sc }}$ & solar cell mass, $\mathrm{kg}$ \\
\hline$M_{\text {te }}$ & trailing edge mass, $\mathrm{kg}$ \\
\hline$M_{\text {tot }}$ & total aircraft mass, $\mathrm{kg}$ \\
\hline $\mathrm{M}_{\mathrm{ts}}$ & tail surface mass, $\mathrm{kg}$ \\
\hline $\mathbf{n}$ & ultimate structural load factor \\
\hline$P_{\text {pay }}$ & payload power, $W$ \\
\hline Pprop & propulsion system power, $W$ \\
\hline$P_{\text {resv }}$ & reserve power, W \\
\hline$P_{\text {sc }}$ & solar cell power, $W$ \\
\hline$P_{\text {tot }}$ & total power, W \\
\hline $\mathrm{R} / \mathrm{C}$ & rate of $\mathrm{climb}, \mathrm{m} / \mathrm{sec}$ \\
\hline $\mathbf{S}$ & unit area, $\mathrm{m}^{2}$ \\
\hline$S_{W}$ & wing area, $\mathrm{m}^{2}$ \\
\hline $\mathbf{t}$ & time of day, 0 at sunrise, $h r$ \\
\hline $\mathbf{t}_{\mathrm{d}}$ & fuel cell discharge time, hr \\
\hline V & aircraft cruising velocity, $\mathrm{m} / \mathrm{sec}$ \\
\hline$V_{\text {wind }}$ & wind velocity, $\mathrm{m} / \mathrm{sec}$ \\
\hline$W$ & aircraft total weight, $n$ \\
\hline$W_{\text {af }}$ & air frame weight, $n$ \\
\hline$\delta$ & declination angle \\
\hline$n_{\text {prop }}$ & propulsion system efficiency \\
\hline nsc & solar cell efficiency \\
\hline$\theta$ & solar elevation angle \\
\hline p & atmospheric density, $\mathrm{kg} / \mathrm{m}^{3}$ \\
\hline$\tau$ & solar attenuation factor \\
\hline$\phi$ & lati tude \\
\hline$\omega$ & hour angle \\
\hline
\end{tabular}

\section{Solar Powered Aircraft Analysis}

For the solar powered aircraft to be able to fly nonstop for extended periods of time, enough energy must be collected and stored during the day to enable the aircraft to fly throughout the night.
This criterion is met by using an energy balance diagram. The solar energy produced by the solar cells per unit area is given by:

$$
\frac{\mathrm{P}_{\mathrm{SC}}}{\mathrm{S}}=580.5 \tau \eta_{\mathrm{SC}} \sin \theta
$$

where $\theta$ is the elevation angle of the sun above the horizon. It is expressed by:

$\theta=90-\cos ^{-1}[\sin \phi \sin \delta+\cos \phi \cos \delta \cos \omega(t)]$

where $\omega(t)$ is the hour angle and is defined as being zero at solar noon, positive before noon and negative after noon with 1 solar hr equaling $14.6^{\circ}$. The expression for $w(t) s$ given by:

$$
\omega(t)=180-14.628 t
$$

By plotting Eq. (1) as a function of time, a value for $P_{\text {tot }} / S_{w}$ can be obtained. This is done by equating the area under the $\mathrm{P}_{\mathrm{SC}} / \mathrm{S}$ curve times the fuel cell efficiency to the area under the $P_{\text {tot }} / S_{W}$ line. This is shown in Fig. A1. Once the equality is obtained the value of $\mathrm{P}_{\text {tot }} / \mathrm{S}_{\mathrm{W}}$ is obtained.

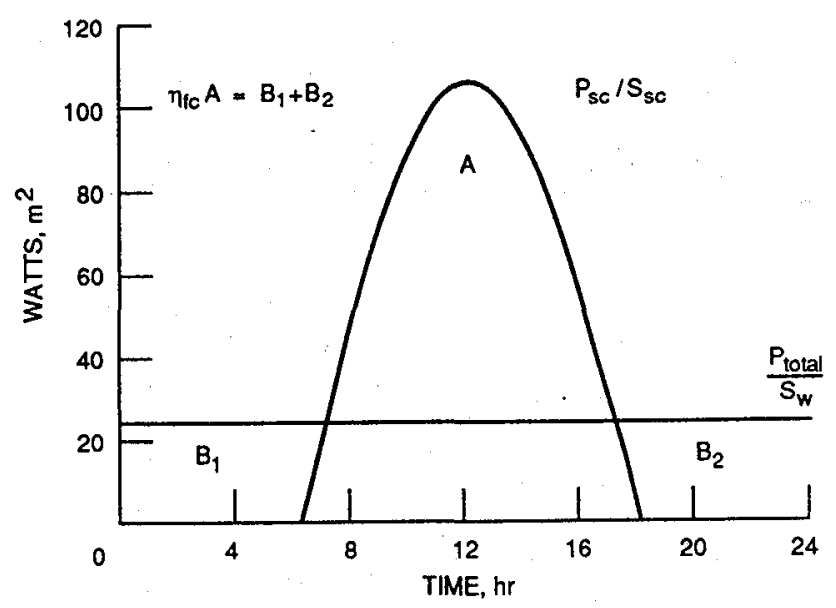

Figure A1. - Solar energy balance diagram for solar powered aircraft analysis.

The $P_{\text {tot }} / S_{w}$ value is then used in the following power conservation equation:

$$
\frac{P_{\text {tot }}}{S_{w}}=\frac{P_{\text {prop }}+P_{\text {pay }}+P_{\text {resv }}}{S_{w}}
$$

Expressions for each term on the right of Eq. (4) are as follows:

$$
\begin{gathered}
\frac{P_{\text {prop }}}{S_{w}}=\frac{1}{{ }_{\text {prop }} S_{w}} \sqrt{\frac{2 W^{3} c_{d}^{2}}{\rho S_{w} C_{l}^{3}}} \\
\frac{P_{\text {resv }}}{S_{w}}=\frac{W}{S_{w}} R / C \\
\frac{P_{\text {pay }}}{S_{w}}=\frac{100}{S_{w}}
\end{gathered}
$$


After substitution of the above terms, Eq. (4) is rearranged to solve for $W / S_{w}$.

Next aircraft weight or sizing equations must be incorporated into the analysis. The expression for airframe weight is taken from Ref. 3 . This expression is as follows:

$$
W_{a f}=A\left(n S_{w} b^{3}\right)^{B}
$$

where $A$ and $B$ are constants which, for ultralight aircraft, have the values 0.325 and 0.357 respectively. Substituting in the expression for aspect ratio (Eq. (9)) and rearranging yields Eq. (10) .

$$
\begin{gathered}
A R=\frac{b^{2}}{S_{w}} \\
A R=\left(\frac{M_{a f} S_{w}^{0.1075}}{S_{w} 0.325 n^{0.357}}\right)^{1.867}
\end{gathered}
$$

An expression for the term $M_{a f} / S_{w}$ is obtained by setting up a conservation of mass equation for the aircraf $t$.

$$
\frac{M_{a f}}{S_{w}}=\frac{M_{t o t}-M_{p r o p}-M_{s c}-M_{f c}-M_{p l}}{S_{w}}
$$

The term $M_{\text {tot }} / S_{w}$ is obtained by combining Eqs. (4) to (7) and solving for wing loading using the maximum endurance parameter value, which is explained later in this section. The other terms are as follows:

$$
\frac{M_{\text {prop }}}{S_{w}}=C_{1}\left[\frac{P_{\text {tot }}}{S_{w}}-R / C \frac{M_{\text {tot }}}{S_{w}}\right]
$$

where $C_{1}$ is the specified specific energy for the array in ki lograms per watt.

$$
\frac{M_{S C}}{S_{w}}=C_{2}\left(\frac{S_{s c}}{S_{w}}\right)
$$

where $C_{2}$ is the specified specific weight for the array in ki lograms per squared meters.

$$
\begin{aligned}
& \frac{M_{f c}}{S_{w}}=\frac{t_{d}^{p} t_{0 t}}{E S_{w}} \\
& \frac{M_{p l}}{S_{w}}=\frac{100}{S_{w}}
\end{aligned}
$$

The $f$ inal set of equations used in the analysis are the aerodynamic equations. These consist of expressions for drag coefficient, lift coefficient and velocity. The drag coefficient is given by:

$$
\begin{gathered}
\mathrm{C}_{\mathrm{d}_{\text {total }}}=\mathrm{C}_{\mathrm{d}_{\text {parasite }}}+\mathrm{C}_{\mathrm{d}_{\text {induced }}} \\
\mathrm{C}_{\mathrm{d}_{\text {parasite }}}=\mathrm{C}_{\mathrm{d}_{\text {wing }}}+\mathrm{C}_{\mathrm{d}_{\text {pod }}}+\mathrm{C}_{\mathrm{d}_{\text {tai }}}+\mathrm{C}_{\mathrm{d}_{\text {boom }}}
\end{gathered}
$$

The values for each parasite drag term in the expression above were obtained form Ref. 9. These values are as follows:

\section{Parasite Drag Coefficient Breakdown}

$\begin{array}{ll}\text { Wing: } & 0.0048 \\ \text { Pod: } & 0.0600 \\ \text { Tail: } & 0.0026 \\ \text { Boom: } & 0.0003\end{array}$

$$
\begin{gathered}
C_{d_{\text {induced }}}=\frac{1.1 \mathrm{C}_{l}^{2}}{\pi A R} \\
V=\sqrt{\frac{2 W_{t o t}}{\rho C_{l} S_{w}}}
\end{gathered}
$$

The aerodynamic expression for endurance parameter is given by $C_{1}^{1.5} / C_{d}$. In order to determine a design point for a given aircraft, the maximum value of the endurance parameter is used. For a given aspect ratio, the lift coefficient which produces a maximum endurance parameter value is given by:

$$
C_{1}=\sqrt{0.1123 \mathrm{AR}}
$$

It should be noted that this expression has incorporated in it the assumed parasite drag coefficients given above.

There is one restriction which is placed on the lift coefficient values which are used in the analysis. They had to be less than or equal to the wind lift coefficient, which is given by:

$$
C_{1_{\text {wind }}}=\frac{2 w_{\text {tot }}}{\rho V_{\text {wind }}^{2} S_{w}}
$$

This was incorporated so that the aircraft would be capable of withstanding 90 percentile winds.

The method of analysis can be summarized into the following four steps.

(1) For a given aspect ratio, calculate the maximum endurance parameter.

(2) Using Eq. (4), power conservation, and the maximum endurance parameter, calculate wing loading.

(3) Using Eq. (11), with the calculated wing loading from step 2 and a given wing area, calculate an aspect ratio.

(4) Check the aspect ratio calculated in step 3 with that given in step 1 . If they do not match, then iterate on the wing area until a match is found or until your wing area limit is exceeded. If no match is found within the given wing area range, then there is no data point at that aspect ratio and it is not aerodynamically possible to fly with that aspect ratio for the conditions given.

A flowchart for the method given above is shown in Fig. A2. 


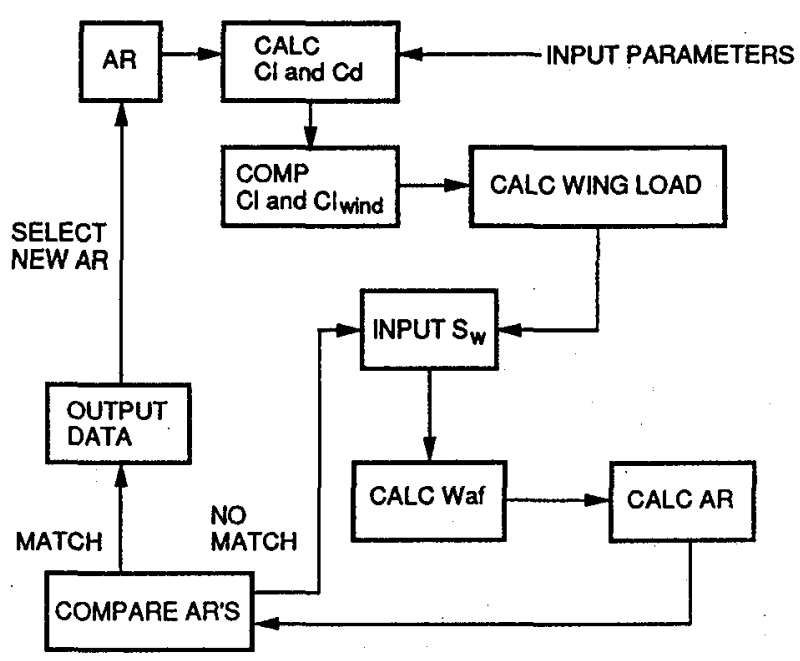

Figure A2. - Computer code flow chart for solar powered aircraft analysis.

\section{Radioisotope Powered Aircraft Analysis}

The structural sizing equations used in the analysis are as follows: 10

Mass spar

$$
M_{S}=0.0026 \mathrm{AR}^{0.9}(1+0.008 \mathrm{AR}) \mathrm{M}_{\text {tot }}
$$

Mass leading edge

$$
M_{1 e}=0.9415 \frac{S_{w}}{\sqrt{A \bar{R}}}
$$

Mass trailing edge

$$
M_{t e}=0.0998 b
$$

Mass covering

$$
M_{\text {Cov }}=0.2055 S_{w}+0.0028 b
$$

Mass ribs

$$
M_{r}=1.033 S_{w}^{0.6}
$$

Mass control

$$
M_{\text {con }}=0.3006 \frac{S_{w}}{\sqrt{\mathrm{AR}}}
$$

Mass fuselage

$$
M_{\text {fus }}=0.0079 \frac{M_{\text {tot }}}{S_{w}}\left(\rho V^{2} S_{w}\right)^{0.9}
$$

Mass tail structure

$$
M_{t s}=3.55 W_{\text {tot }}^{0.87}\left(\mathrm{cS}_{w}\right)^{-0.6}
$$

Mass propeller

$$
M_{p}=10.27\left(\frac{M_{t o t}}{S_{w}}\right)^{0.5}
$$

Besides the addition of the above equations, the analysis had to be adapted to the characteristics of the radioisotope power source. Since no storage of energy was necessary for continuous flight, there was no longer a need for an energy balance diagram or solar intensity equations. The conservation of mass equation (Eq. (2)) had to be altered to accommodate the different aircraft components. The rewritten equation is as follows:

$$
\frac{M_{\text {af }}}{S_{w}}=\frac{M_{\text {tot }}-M_{\text {prop }}-M_{p l}-M_{h s}}{S_{w}}
$$

The expressions for some of the terms on the right side of the above equation are as follows:

$$
\frac{M_{\text {prop }}}{S_{w}}=C_{3}\left(\frac{P_{\text {tot }}}{S_{w}}\right)
$$

where $C_{3}$ is the specified weight of the propulsion system in kilograms per watt.

$$
\frac{M_{h s}}{S_{w}}=\frac{P_{\text {tot }} C_{4}}{S_{w}{ }_{\text {prop }}}
$$

where $C_{4}$ is the specific power of the isotope heat source in ki lograms per watt.

To incorporate the structural sizing equations into the design, an additional two steps had to be added to the solar plane analysis. These steps are as follows:

(5) Calculate the airframe weight, using the structural sizing equations.

(6) Compare the calculated airframe weight to the airframe weight obtained in the analys is (from Eq. (22)). If the calculated airframe weight is greater than that allotted in the analysis, then increase the wing area, recalculate the endurance parameter which is no longer a maximum, and redo steps 2 to 6 . Continue with this process until the airframe weight requirement is satisfied or until the range of desirable wing areas is exhausted.

A flowchart for the two added steps is shown in Fig. A3.

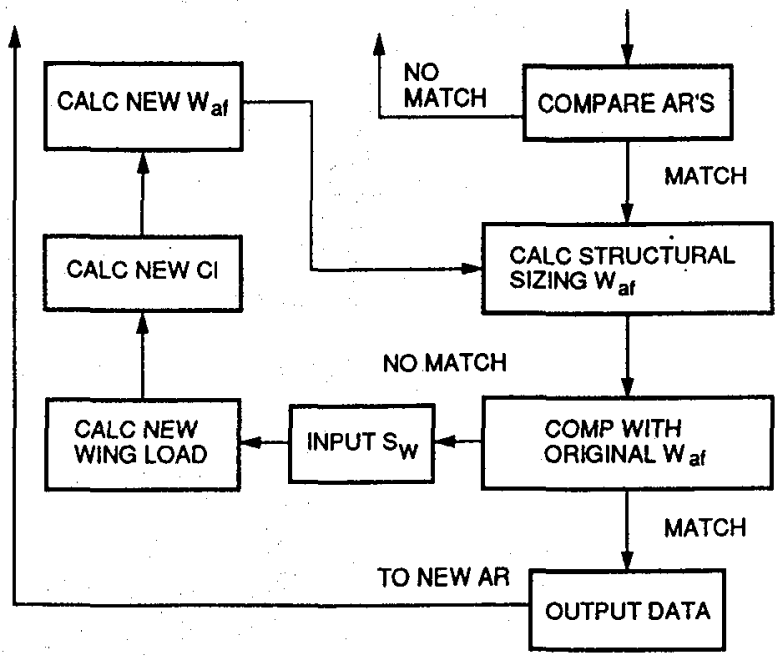

Figure A3. - Computer code flow chan addition for radioisotope powered aircraft analysis. 


\section{References}

1. Hal1, D.W., For tenbach, C.D., Dimiceii, E.V. and Parks, R.W., "A Preliminary Study of Solar Powered Aircraft and Associated Power Trains," NASA CR-3699, 1983.

2. Youngblood, J.F. and Jackson, R.D., "Airborne

- Reconnaissance in the Civilian Sector: Agricultural Monitoring from High-Altitude Powered Platforms," Presented at the SPIE Annual International Technical Symposium and Instrument Display, 27th, San Diego, CA, Aug. 21-26, 1983.

3. Youngblood, J.W., Talay T.A. and Pegg, R.J., "Design of Long-Endurance Unmanned Airplanes incorporating Solar and Fuel Cell Propulsion," AIAA Paper 84-1430, June 1984.

4. Youngblood, J.H. and Talay, T.A., "Solar-Powered Airplane Design for Long Endurance, HighAltitude Flight," AlAA Paper 82-081 1, May 1982.

5. MacCready, P.B., Licsaman, P., Morgan, W.R. and Burke, J.D., "Sun Powered Aircraft Design," AlAA 81-0916, May 1981.

6. Boucher, R.J., "Project Sunrise - A Flight Demonstration of Astro Flight Model 7404 Solar Powered Remotely Piloted Vehicle," Air Force Contract F3361 5-74-C-2053, Nov. 1975. (Also, AIAA Paper 79-1264, June 1979.)

7. Foch, R.J., Wyatt, R.E. and Randal 1, E., "Low Alt i tude/Airspeed Unmanned Research Aircraft (LAURA) Preliminary Development," Aerodynamics at Low Reynolds Numbers Re Greater Than 10 to the $4 \mathrm{th}$ and Less Than 10 to the 6 th; Proceedings of the International Conference, Vol. 3, Royal
Aeronautical Society, London, England, 1986, pp. $31.1-31.29$

8. "A Concept Study of a Remotely Piloted Vehicle for Mars Exploration," NASA CR-157942, 1978.

9. McCormick, B.W., Aerodynamics, Aeronautics and Flight Mechanics, John Wiley and Sons, New York, 1979 .

10. Hall, D.W. and Hall, S.A., "Structural Sizing of a Solar Powered Aircraft," Lockheed Missiles and Space Company, NASA CR-172313, 1984.

11. "SPE Regenerative Fuel Cell Review," Internal Report, Hamilton Standard Electro-Chem Inc., Jan. 1985.

12. Irving, F.G. and Morgan, D., "The Feasibility of an Aircraft Propelled by Solar Energy," AlAd Paper 74-1042, Sept. 1974.

13. Sherwin, K., "Selection of Aerfoil Sections for Use in Man-Powered Aircraft," Aerodynamics at Low Reynolds Numbers Re Greater Than 10 to the 4th and Less Than 10 to the 6th: Proceedings of the International Conference, Vol. 3, Royal Aeronautical Society, London, England, 1986 , pp. 33.1-33.8.

14. Williams, B.R., "The Calculation of Flow About Aerfoils at Low Reynolds Numbers with Application to Remotely Piloted Vehicles," Aerodynamics at Low Reynolds Numbers Re Greater Than 10 to the 4 th and Less Than 10 to the 6 th; Proceedings of the International Conference, Vol. 3, Royal Aeronautical Society, London, England, 1986, pp. 22,1-22.49. 


\section{Report Documentation Page}

\begin{tabular}{|l|l|}
\hline $\begin{array}{c}\text { 1. Report No. NASA CR-185243 } \\
\text { AIAA-90-2000 }\end{array}$ & 2. Government Acc \\
\hline $\begin{array}{l}\text { 4. Title and Subtitle } \\
\text { Preliminary Design of a Long-Endurance Mars Aircraft }\end{array}$
\end{tabular}

Preliminary Design of a Long-Endurance Mars Aircraft

3. Recipient's Catalog No.

5. Report Date

April 1990

6. Performing Organization Code

7. Author(s)

Anthony J. Colozza

8. Performing Organization Report No.

None

$(\mathrm{E}-5475)$

10. Work Unit No

591-11-31

9. Performing Organization Name and Address

Sverdrup Technology, Inc.

Lewis Research Center Group

11. Contract or Grant No.

NAS3-25266

2001 Aerospace Parkway

Brook Park, Ohio 44142

12. Sponsoring Agency Name and Address

National Aeronautics and Space Administration

Lewis Research Center

Cleveland, Ohio 44135-3191

15. Supplementary Notes

Project Manager, David Bents, Power Technology Division, NASA Lewis Research Center. Prepared for the 26th Joint Propulsion Conference, cosponsored by the AIAA, SAE, ASME, and ASEE, Orlando, Florida, July 16-18, 1990.

16. Abstract

The preliminary design requirements of a long-endurance aircraft capable of flight within the Martian environment was determined. Both radioisotope/heat engine and PV solar array power production systems were considered. Various cases for each power system were analyzed in order to determine the necessary size, weight and power requirements of the aircraft. The analysis method used was an adaptation of the method developed by J.W. Youngblood and T.A. Talay of NASA Langley Research Center used to design a high-altitude Earth based aircraft. The analysis is set up to design an aircraft which, for the given conditions, has a minimum wingspan and maximum endurance parameter. The results showed that, for a first approximation, a long-endurance aircraft is feasible within the Martian environment. The size and weight of the most efficient solar aircraft were comparable to the radioisotope powered one.

17. Key Words (Suggested by Author(s))

Mars aircraft; Long-endurance aircraft; Mars rovers; Mars exploration; Low Reynolds numbers; Aircraft; Power technology for long endurance flight
18. Distribution Statement

Unclassified-Unlimited

Subject Category 07

19. Security Classif. (of this report)

20. Security Classif. (of this page)

21. No. of pages

22. Price $^{*}$

Unclassified

Unclassified

14 

National Aeronautics and

Space Administration

Lewis Research Center

Cleveland, Ohio 44135

Official Business

Penalty for Private Use $\$ 300$
FOURTH CLASS MAIL

ADDRESS CORRECTION REQUESTED
|||||

Postage and Fees Paid Natıonal Aeronautics and

Space Admınıstratıon

NASA 451 